\title{
INVESTMENT DECISION MAKING USING A COMBINED FACTOR ANALYSIS AND ENTROPY-BASED TOPSIS MODEL
}

\author{
Li-Chang Hsu \\ Department of Finance, Ling Tung University, 1 Ling Tung Road, Nantun, \\ Taichung, 40852, Taiwan, R.O.C. \\ E-mail: ltctht87@mail.ltu.edu.tw
}

Received 08 August 2011; accepted 11 October 2011

\begin{abstract}
Traditionally, the return on assets and the return on equity are used as the criteria in the evaluation of financial performance, while risk considerations are ignored. Therefore, this study combined financial ratio variables and the RAROC (risk-adjusted rate of return on capital) as the evaluation criteria and developed a financial performance evaluation model. The proposed evaluation model combines factor analysis with entropy weight and the TOPSIS (technique for order performance by similarity to ideal solution) to evaluate the financial performance of Taiwan's 50 listed opto-electronic companies. Finally, Spearman's and Kendall's rank correlations are used to verify that there is no significant difference between the 2007 and 2008 rankings of the companies. The empirical results show the financial performance rankings of the companies before and after the global financial turmoil. These findings not only help investors making investment decisions, but also can help managers make decisions to improve their company's financial performance.
\end{abstract}

Keywords: decision making, financial performance evaluation, RAROC, TOPSIS, factor analysis, entropy weight, opto-electronic companies.

Reference to this paper should be made as follows: Hsu, L.-C. 2013. Investment decision making using a combined factor analysis and entropy-based TOPSIS model, Journal of Business Economics and Management 14(3): 448-466.

JEL Classification: G11, G31, G32, C44, L25, L86.

\section{Introduction}

Performance evaluation of enterprises is an important part in modern enterprise management. Advantages and disadvantages of financial performance may represent whether the operating ability of an enterprise is good or bad. Financial performance evaluation can also better display enterprise's future growth and development potential. In the early days, return on assets (ROA) and return on equity (ROE) were the two main indicators used in financial performance evaluation. However, ROA and ROE cannot represent the true operating performance of an enterprise. Therefore, a number of financial ratios have been selected to measure companies' financial performance. However, from an 
enterprise's point of view, all investments and all profits have different risks. Therefore, enterprises use capital to create profits, but also to bear the risk of loss. This means that the performance evaluation criteria must be combined with risk indicators; this can express the advantages and disadvantages of financial performance more accurately and thoroughly.

There are still many problems in the field of financial performance evaluation, such as: (1) how to determine the evaluation criteria?, (2) how to evaluate the performance? Measures of financial performance do not only show the enterprise's financial conditions or operating loss. In fact, the real purpose of financial performance evaluation is to identify the impact of influential factors on the financial situation and to assist enterprise managers in improving the future direction of their companies. Through a review of previous literature, many researchers use different methods to evaluate the financial performance of companies. One of the most widely used methods is traditional financial ratios analysis (Laitinen 2000). For example, Seçme et al. (2009) used 27 financial ratios to measure a bank's financial performance evaluation. Walsh (1996) also pointed out that the use of financial ratios as an indicator of business evaluation is the most appropriate because it provides clear goals and standards. Wang $(2008,2009)$ used ratio analysis (21 financial ratios) for financial performance evaluation, and in order to avoid repeated evaluation on the same financial ratios, financial ratios were classified into several clusters. Yurdakul and İç (2004) used financial ratios as a measure of variables in the analytical hierarchy process (AHP) model, followed by the TOPSIS method to obtain financial performance scores of Turkish automotive companies and textile companies. Therefore, this study also uses financial ratios as an indicator of enterprise performance evaluation.

Multiple criteria decision making (MCDM) is a decision-making process which is used for performance evaluation. The use of MCDM techniques for company's performance evaluation can be divided into two parts: the first part ensures the weight of the evaluation criteria and the second part obtains the ranking of each company. When the weight of the criteria identified, the performance criteria selected for performance evaluation is one of the important topics. The weight method can be basically classified into two types: subjective weight and objective weight (Xie et al. 2008). Both methods have their strengths and weaknesses. The subjective weight method has the advantage of explaining the evaluation clearly, and the objective weight method is applied to explain the evaluation in data (Wang et al. 2008). For a recent review of the application of the weight methods, the entropy weight is a kind of objective weight. This kind of weight has been used in performance evaluation studies (Chang et al. 2010; Chiang, Hsieh 2009; Chou, Tsai 2009; Wang et al. 2008; Wang, Lee 2009; Zou et al. 2006). Therefore, this study uses the entropy method to calculate the weight of performance evaluating indicators.

In previous studies of MCDM (Zavadskas, Turskis 2011), many methods have been proposed and widely used in the ranking of performance evaluation, such as the Simple Additive Weighting (SAW) (Ginevičius et al. 2008; Podvezko 2011; Žvirblis, 
Buračas 2010), AHP (Medineckiene et al. 2010; Podvezko et al. 2010; Sivilevičius, Maskeliūnaitė 2010; Wu et al. 2007), Elimination and Choice Translating Reality (ELECTRE) family (Parthiban et al. 2010; Radziszewska-Zielina 2010; Wang, Triantaphyllou 2008; Ulubeyli, Kazaz 2009), Preference Ranking Organization Method for Enrichment Evaluation (PROMETHEE) (Behzadian et al. 2010; Podvezko, Podviezko 2010; Tomić-Plazibat et al. 2010), Vlse Kriterijumska Optimizacija I Kompromisno Resenje (VIKOR) (Antucheviciene, Zavadskas 2008; Ginevičius et al. 2010; Ou Yang et al. 2011; Shan 2011), TOPSIS (Chang et al. 2010; Ertuğrul, Karakasoğlu 2009; Ginevičius et al. 2010; Han, Liu 2011; Liu 2011a; Yu, Hu 2010), Additive Ratio Assessment (ARAS) method (Tupenaite et al. 2010; Turskis, Zavadskas 2010; Zavadskas et al. 2010a), Complex Proportional Assessment (COPRAS) (Kaklauskas et al. 2010; Kildienè et al. 2011; Uzsilaityte, Martinaitis 2010), Multi-Objective Optimization by Ratio Analysis (MOORA) (Brauers et al. 2010; Chakraborty 2011; Gadakh 2011) and MOORA plus Full Multiplicative Form (MULTIMOORA) (Baležentis et al. 2010; Brauers, Ginevičius 2010; Brauers, Zavadskas 2010). TOPSIS is one of the most popular approaches for the MCDM method. It can help managers carry out decision analysis (Yu, $\mathrm{Hu}$ 2010). Meanwhile, it is also a useful tool for dealing with multi-attribute decisionmaking (MADM) problems (Han, Liu 2011; Liu 2009, 2011b, 2011c). There have been many applications of TOPSIS in previous performance evaluation studies. For example, Chang et al. (2010) extended the TOPSIS method to the performance evaluation of 82 Taiwanese mutual funds. Ertuğrul and Karakasoğlu (2009) used the TOPSIS method to evaluate the performance of fifteen Turkish cement firms. Yu and $\mathrm{Hu}$ (2010) used the fuzzy TOPSIS method to evaluate the performance of multiple manufacturing plants in a fuzzy environment.

Similarly, the TOPSIS method can also be used for financial performance evaluation. For instance, Deng et al. (2000) used multiple financial ratios as assessment criteria, and constructed a modified TOPSIS method for ranking of competing company's financial performance. Seçme et al. (2009) used the TOPSIS method to study a bank's financial, non-financial and total performance rankings. Wang (2008) used the fuzzy TOPSIS method to evaluate the financial performance of Taiwan domestic airlines.

According to Hwang and Yoon (1981), and Wang (2008, 2009), financial performance evaluation is a MCDM problem. Thus, based on the studies mentioned above, TOPSIS is a classical MCDM method (Zavadskas et al. 2010b), and is appropriate for the financial performance evaluation of companies.

In light of previous studies, the use of financial ratios modeled in financial decision making creates multicollinearity problems (Machfoedz 1994). Therefore, this study takes multicollinearity between financial ratios into account, by using factor analysis to reduce or eliminate multicollinearity (Zopounidis, Dimitras 1998), and to select representative financial ratios. In order to correct the problem that traditional measures of financial performance do not take risk into account (Karandikar et al. 2007), we use RAROC as a risk indicator. Then we use the selected financial ratios combined with RAROC as evaluation criteria. Finally, by using Shannon's entropy (Shannon, Weaver 
1949) to calculate the criteria weights and the TOPSIS method for ranking the company's financial performance, the proposed method is referred to as the entropy-based TOPSIS model.

For the purpose of testing the applicability of the proposed process for evaluating financial performance, and to discuss the changes in the companies' financial performance before and after the financial turmoil, this study uses Taiwan's listed opto-electronic companies as an empirical case. Through factor analysis combined with the entropybased TOPSIS model, we evaluate the financial performance of these companies in 2007 and 2008. Finally, the Spearman and Kendall rank correlation test is used to assess the significance of rank correlations between 2007 and 2008. The results will allow managers and investors to better understand their company's financial performance and financial position. Moreover, it may serve as a reference for investment and credit decision making for shareholders and creditors.

The rest of this paper is organized as follows. Section 2 determines the appropriate performance evaluation criteria. Section 3 gives a detailed description of the performance evaluation methods. Section 4 presents an analysis of the empirical results. The final section offers a conclusion and recommendations.

\section{Criteria for a performance evaluation}

Financial statement analysis is important to a company's managers and investors who make judgments about the financial health of the enterprise. Financial ratio analysis is a widely accepted technique of financial statement analysis (Rathore et al. 2010). This technique uses a balance sheet and income statement of the data to calculate and compare financial ratios for each company. Financial ratios are calculated to evaluate the financial situation of a company. There are many financial ratios. However, how to choose the criterion of performance evaluation is an issue worth exploring. In general, there is a lack of a theoretical foundation to guide the selection of ratios as the criteria for financial ratios (Charitou et al. 2004). In this study, two criteria were applied to ratio selection: (1) select ratios according to previous studies, (2) availability of financial data. According to criteria above, 20 financial ratios were obtained for this study.

In the late 1970s, Bankers Trust developed RAROC as a performance evaluation tool (Froot, Stein 1998). RAROC is an indicator used to measure risk adjusted financial performance, and it is a simple and effective tool. In general, RAROC is defined as the ratio of (expected) return minus risk adjustment to economic capital (Farzam 2009). In this study, we consider the manager in order to measure the risk of possible returns per dollar on each investment. So, RAROC was considered as a performance evaluation indicator and defined as (Unrealized gains and losses/Days)/(Value at Risk/t). The definitions of the 20 financial ratios and RAROC are listed in Table 1. 
Table 1. Summary of indicator definitions for all variables used in the empirical analysis

\begin{tabular}{|c|c|c|}
\hline Indicator & Variable & Definitions \\
\hline Long-term capital ratio & K1 & $\begin{array}{l}\text { (Net shareholder's equity + Long-term liabilities)/ } \\
\text { Net fixed assets }\end{array}$ \\
\hline Quick ratio & $\mathrm{K} 2$ & (Current assets - Inventories)/Current liabilities \\
\hline Current ratio & K3 & Current assets/Current liabilities \\
\hline Accounts receivable in days & K4 & 365/Accounts receivable turnover ratio \\
\hline Fixed assets turnover & K5 & Net operating revenue/Total fixed assets \\
\hline Returns on equity & K6 & Current term net profit/Shareholder equity \\
\hline Cash flow adequacy ratio & K7 & $\begin{array}{l}\text { Net cash flow operation over the last five years/ } \\
\text { (Capital spending + Addition to inventory + Cash } \\
\text { dividend) over the five years }\end{array}$ \\
\hline $\begin{array}{l}\text { Pre-tax income on paid-in } \\
\text { capital ratio }\end{array}$ & K8 & Pre-tax income/Paid-in capital \\
\hline Earnings per share & K9 & Net income/Shares outstanding \\
\hline Cash flow ratio & K10 & Cash flow from operation/Current liabilities \\
\hline Cash reinvestment ratio & K11 & $\begin{array}{l}\text { (Net cash flow from operating activities-Cash } \\
\text { dividend)/(Total fixed assets + Long-term } \\
\text { investments + Other assets + Working capital) }\end{array}$ \\
\hline Operating profit ratio & K12 & Operating profit/Net sales \\
\hline Net profit rate & K13 & Earning/Net sales \\
\hline Accounts receivable turnover & K14 & Net sales/Average balance of account receivable \\
\hline Inventory turnover & K15 & Cost of sales/Average inventory \\
\hline Total assets turnover & K16 & Net operating revenue/Total assets \\
\hline Returns on assets & K17 & $\begin{array}{l}{[\text { Earning }+ \text { Interest expenses } \times(1 \text {-tax rate })] /} \\
\text { Average total assets }\end{array}$ \\
\hline Debt ratio & K18 & Total debt/Total assets \\
\hline Times interest earned & K19 & $($ Net income + Interest expense)/Interest expense \\
\hline Average daily sales & K20 & $365 /$ Inventory turnover \\
\hline RAROC & K21 & $\begin{array}{l}\text { (Unrealized gains and losses /Days)/ } \\
\text { (Value at Risk /t) }\end{array}$ \\
\hline
\end{tabular}

\section{Performance evaluation methods}

This study used factor analysis to select the important variables that affect the performance evaluation, and then carried out performance evaluation through the entropy weight and TOPSIS methods. Factor analysis, entropy weight, and the TOPSIS method are described below.

\subsection{Factor analysis}

Factor analysis is one of the most efficient methods for identifying the underlying dimensions in a group of variables. It hypothesizes that the reason why there are correlations between each variable is because there are a few basic factors which influence 
these variables. The main purpose of factor analysis is to discover those jointly basic factors and apply them to eliminate redundant variables. This method has been widely used in financial analysis. For example, Charbaji (2001) used factor analysis as a data reduction technique to reduce the financial ratios of Lebanon banks from 52 into 7 financial ratios. Cheng and Arif (2007) used factor analysis in Malaysia commercial banks to reduce 21 accounting and financial ratios into four factors. Öcal et al. (2007) used factor analysis in a Turkish construction company's 50 financial ratios, in order to determine the financial indicators.

Usually, the analytical steps in factor analysis can be described as follows: (1) compute the correlation coefficient matrix of measurable variables, (2) compute Bartlett's test of specificity to test the adequacy of the sample population, (3) compute the Kaiser-Myer Olkin (KMO) measure of sampling adequacy, (4) principal component analysis is the factor extraction method used, (5) compute the factor pattern/structure coefficients for each measurable variable, (6) Varimax with Kaiser Normalization is used in the Rotation method to determine the number of factors to be extracted from the dataset.

\subsection{Entropy weight method}

Entropy was proposed by Shannon (1948). He used the concept of informational entropy to measure message uncertainty. The greater the entropy value, the greater the uncertainty. The entropy method has been widely used for evaluating the weights of indicators (i.e., entropy weight method). For instance, Hsu, P. F. and Hsu, M. G. (2008) used the entropy method to calculate the weight of each criterion for medical information system vendors, in order to objectively assess the quality of an information technology supplier. Kildienè et al. (2011) combined entropy and COPRAS methods to evaluate the priority of the European country construction sectors set. Liu et al. (2010) used the entropy theory to determine the weight of indicators in water quality assessment. Saparauskas et al. (2011) used entropy and three efficiency criteria to evaluate different building facades. Shanian and Savadogo (2009) shows that the results of entropy weights can help the designer select the proper criteria in the design of the components, and entropy is the appropriate method. Zou et al. (2006) used the entropy method to calculate the weight of evaluating indicators in water quality assessment of the three reservoir areas. Therefore, this study uses the entropy weight method to calculate the weights of indicators. The steps of the entropy weight method are as follows.

Step 1: Normalization of the original evaluating matrix.

Firstly, use $n$ evaluating indicators and $m$ evaluating objects to construct the original evaluation matrix $D$.

$$
D=\left[x_{i j}\right]_{m \times n}=\left[\begin{array}{cccc}
x_{11} & x_{12} & \cdots & x_{1 n} \\
x_{21} & x_{22} & \cdots & x_{2 n} \\
\vdots & \vdots & \cdots & \vdots \\
x_{m 1} & x_{m 2} & \cdots & x_{m n}
\end{array}\right]_{m \times n} \text {, }
$$

where $i=1,2, \ldots, m, j=1,2, \ldots, n$. 
Then, the normalized evaluation matrix $R=\left[\gamma_{i j}\right]$ can be calculated by the original evaluation matrix $D$. Where $\gamma_{i j}$ is the data of the $i$-th evaluating object on the $j$-th indicator, and $\gamma_{i j} \in[0,1]$. According to Chiang and Hsieh (2009), there are three different types of data normalization. Among these indicators, to the larger they are the better:

the smaller they are the better:

$$
\gamma_{i j}=\frac{x_{i j}-\min _{i} x_{i j}}{\max _{i} x_{i j}-\min _{i} x_{i j}},
$$

while, the more they are nominal the better:

$$
\gamma_{i j}=\frac{\max _{i} x_{i j}-x_{i j}}{\max _{i} x_{i j}-\min _{i} x_{i j}},
$$

$$
\gamma_{i j}=\frac{\left|x_{i j}-x_{o b j}\right|}{\max _{i} x_{i j}-x_{o b j}},
$$

where $\max x_{i j} \geq x_{i j} \geq \min x_{i j}, x_{o b j}$ is the desired value of the $j$-th quality characteristic. So we have the followihg normalized evaluation matrix:

$$
R=\left[\begin{array}{cccc}
\gamma_{11} & \gamma_{12} & \cdots & \gamma_{1 n} \\
\gamma_{21} & \gamma_{22} & \cdots & \gamma_{2 n} \\
\vdots & \vdots & \ddots & \vdots \\
\gamma_{m 1} & \gamma_{m 2} & \cdots & \gamma_{m n}
\end{array}\right]_{m \times n}
$$

Step 2: Weight of each indicator based on entropy.

According to Chiang and Hsieh (2009), the steps for weight calculation are as follows:

(1) Calculate the sum of the indicator in all sequences:

$$
D_{j}=\sum_{i=1}^{m} \gamma_{i j}, j=1,2, \ldots, n
$$

(2) Find the normalized coefficient:

$$
K=\frac{1}{\left(e^{0.5}-1\right) m}=\frac{1}{0.6487 m} .
$$

(3) Calculate the entropy of each indicator:

$$
e_{j}=\frac{1}{0.6487 m} \sum_{i=1}^{m} W e\left(\frac{\gamma_{i j}}{D_{j}}\right),
$$

where $j=1,2, \ldots, n, W_{e}=x e^{(1-x)}+(1-x) e^{x}-1$.

(4) Calculate the sum of entropy:

$$
E=\sum_{j=1}^{n} e_{j}
$$

(5) Calculate the weight of each indicator:

$$
w_{j}=\frac{\frac{1}{n-E}\left[1-e_{j}\right]}{\sum_{j=1}^{n} \frac{1}{n-E}\left[1-e_{j}\right]}, j=1,2, \ldots, n .
$$




\subsection{Entropy-based TOPSIS model}

The TOPSIS method is a multi-criteria decision making method which was first introduced by Hwang and Yoon (1981). The basic concepts of TOPSIS come from the compromise solution, which can be used to resolve conflicts between attributes and can help experts to complete decision-making methods. Previous studies have also pointed out that the TOPSIS method has many advantages. For example, Abo-Sinna and Amer (2005) pointed out that the TOPSIS method is simple, intuitive, and easily accepted by policy makers. Deng et al. (2000) mentioned that TOPSIS is a simple and easy way to calculate the evaluation method. Shih et al. (2007) also stated that among the MCDM methods, the TOPSIS evaluation method is the most clear and intuitive method for decision-making.

Therefore, this study uses the TOPSIS method combined with entropy weight to evaluate the financial performance of companies. The steps of the entropy-based TOPSIS model can be summarized as follows.

Step 1: Construct normalized decision matrix $\left[\gamma_{i j}\right]_{m \times n}$.

Suppose there are $\mathrm{m}$ evaluating objects and $\mathrm{n}$ indicators. Then, according to Eq. (1), we can obtain the decision matrix, $D$. Since the evaluation criteria for data have no uniform dimension, we need to normalize the data. In the normalization process, different indicators have to be applied to the benefit criteria and to the cost criteria (Wang 2008, 2009). Among these indicators, the benefit criteria is shown as:

$$
\gamma_{i j}=\frac{x_{i j}}{\sqrt{\sum_{i=1}^{m} x_{i j}^{2}}}
$$

the cost criteria are shown as:

$$
\gamma_{i j}=\frac{1 / x_{i j}}{\sqrt{\sum_{i=1}^{m}\left(1 / x_{i j}\right)^{2}}} .
$$

The normalized decision matrix is constructed using Eqs. (11) and (12) (Wang 2008, 2009).

Step 2: Construct the weighted normalized decision matrix:

$$
V=\left(v_{i j}\right)_{m \times n}=\left[\begin{array}{cccc}
w_{1} \gamma_{11} & w_{2} \gamma_{12} & \cdots & w_{n} \gamma_{1 n} \\
w_{1} \gamma_{21} & w_{2} \gamma_{22} & \cdots & w_{n} \gamma_{2 n} \\
\vdots & \vdots & \cdots & \vdots \\
w_{1} \gamma_{m 1} & w_{2} \gamma_{m 2} & \cdots & w_{n} \gamma_{m n}
\end{array}\right],
$$

where $w_{j}$ is the entropy weight of the $j$-th criterion from Eq. (10), and $\sum_{j=1}^{n} w_{j}=1$.
Step 3: Determine the ideal and negative-ideal solution, respectively.

Calculate the weighted evaluated value of the plus and minus ideal solution: 


$$
\begin{aligned}
& V^{+}=\left\{\left(\max _{i} v_{u j} \mid j \in J\right) \mid i=1,2, \ldots, m\right\}=\left(v_{1}^{+}, v_{2}^{+}, \ldots, v_{j}^{+}, \ldots, v_{n}^{+}\right), \\
& V^{-}=\left\{\left(\min _{i} v_{i j} \mid j \in J\right) \mid i=1,2, \ldots, m\right\}=\left(v_{1}^{-}, v_{2}^{-}, \ldots, v_{j}^{-}, \ldots, v_{n}^{-}\right) .
\end{aligned}
$$

Step 4: By using Euclidean distance, we can calculate the separation measures.

The Euclidean distances, between $V_{i}$ and $V^{+}$, and between $V_{i}$ and $V^{-}$are calculated, respectively, as

$$
\begin{aligned}
& S_{i}^{+}=\sqrt{\sum_{j=1}^{n}\left(v_{i j}-v_{j}^{+}\right)^{2}}, i=1,2, \ldots, m, \\
& S_{i}^{-}=\sqrt{\sum_{j=1}^{n}\left(v_{i j}-v_{j}^{-}\right)^{2}}, i=1,2, \ldots, m .
\end{aligned}
$$

Step 5: Calculate the closeness coefficient.

The closeness coefficient of each object with an ideal solution is calculated as:

Step 6: Rank the preference order.

$$
C_{i}=\frac{S_{i}^{-}}{S_{i}^{+}+S_{i}^{-}} .
$$

A closeness coefficient is defined to determine the ranking order of all alternatives. The higher the value of the closeness coefficient the better the rank.

\subsection{Rank correlation methods}

In statistics, the two most well-known rank correlation coefficients are the Spearman (1904) and the Kendall (1970) rank correlation coefficient. Recently, Athawale and Chakraborty (2011) used Spearman's and Kendall's rank correlation to compare the relative performance of ten most well-known MCDM methods. Similarly, Alinezhad et al. (2011), Brauers et al. (2011) and Keršuliene et al. (2010) also used the two rank correlation methods to solve the ranking problems. Therefore, we use both the Spearman and the Kendall rank correlation coefficient to measure the financial performance evaluation rank correlation. The Spearman and Kendall rank correlation coefficients are appropriate statistically and useful in analysis of ordinal data (Wilcke et al. 2009). The two correlation measures are defined as follows:

Spearman's correlation coefficient is given by

$$
\gamma_{S}=1-\frac{6 \sum D^{2}}{n\left(n^{2}-1\right)},
$$

where $D$ is the difference between paired ranks; $n$ is the number of paired items; Spearman's correlation ranges from -1 to 1 .

Kendall's correlation coefficient is given by

$$
\tau=\frac{4 p}{n(n-1)}-1,
$$

where $p$ is the number of pairs of items; the coefficient ranges from -1 to 1 . 


\section{Empirical results}

Empirical analysis of the evaluation process is described below. First, factor analysis uses the principal component procedure to reduce the dimensionality of the financial ratios. Then, the entropy-based TOPSIS model is used to rank financial performance.

\subsection{Data sources}

In order to more accurately evaluate the financial performance, this study uses financial and risk variables to construct a financial performance evaluation model. A total of 50 listed opto-electronic companies in Taiwan with 20 financial ratios from Taiwan Economics Journal (TEJ) and 1 risk variable (RAROC) from TEJ VaR system v2.1 were examined. The period of study covers 2007 and 2008.

\subsection{Results of factor analysis}

Factor analysis was the technique used to reduce the number of variables. The main purpose was to reduce the data with many variables (dimensions) into data with fewer dimensions, while still keeping most of the information from the original data. The SPSS 16 was used for factor analysis, and the empirical results are shown in Table 2.

Table 2. The results of factor analysis

\begin{tabular}{|c|c|c|c|c|c|}
\hline Factor & Variable & Factor loading & Eigenvalue & $\%$ of variance & Selected \\
\hline \multirow{6}{*}{ Profitability } & K6 & 0.955 & \multirow{6}{*}{4.83} & \multirow{6}{*}{$24.149 \%$} & $*$ \\
\hline & K8 & 0.912 & & & $*$ \\
\hline & K9 & 0.851 & & & $*$ \\
\hline & K12 & 0.817 & & & \\
\hline & K13 & 0.673 & & & \\
\hline & K18 & -0.596 & & & \\
\hline \multirow{4}{*}{$\begin{array}{l}\text { Short-term } \\
\text { liquidity }\end{array}$} & K3 & 0.959 & \multirow{4}{*}{3.53} & \multirow{4}{*}{$17.657 \%$} & $*$ \\
\hline & $\mathrm{K} 2$ & 0.943 & & & $*$ \\
\hline & K10 & 0.839 & & & * \\
\hline & K19 & 0.784 & & & \\
\hline \multirow{4}{*}{$\begin{array}{l}\text { Financial } \\
\text { structure }\end{array}$} & $\mathrm{K} 5$ & 0.944 & \multirow{4}{*}{2.823} & \multirow{4}{*}{$14.113 \%$} & $*$ \\
\hline & K1 & 0.869 & & & $*$ \\
\hline & K16 & 0.757 & & & \\
\hline & K20 & -0.527 & & & \\
\hline \multirow{3}{*}{$\begin{array}{l}\text { Operating } \\
\text { capability }\end{array}$} & K4 & 0.892 & \multirow{3}{*}{1.866} & \multirow{3}{*}{$9.328 \%$} & $*$ \\
\hline & K14 & -0.718 & & & \\
\hline & K17 & 0.489 & & & \\
\hline \multirow{2}{*}{$\begin{array}{l}\text { Long-term } \\
\text { liquidity }\end{array}$} & K15 & 0.781 & \multirow{2}{*}{1.41} & \multirow{2}{*}{$7.049 \%$} & \\
\hline & K11 & 0.694 & & & \\
\hline Cash flow & K7 & -0.891 & 1.27 & $6.355 \%$ & $*$ \\
\hline \multicolumn{3}{|l|}{ Cumulative \% } & \multicolumn{3}{|c|}{$78.651 \%$} \\
\hline
\end{tabular}


This study used factor analysis based on principal component analysis as the extraction method and adopted Varimax with Kaiser Normalization as the rotation method. In principal component analysis key test, we have to analyze the KMO and Bartlett's test. In this case, the KMO is greater than 0.5 at 0.552 and Bartlett's test is significant $\left(\chi^{2}(190)=1001.09, p<0.001\right)$ and, therefore, it seems that the sample is adequate for factor analysis.

The results of the principal component analysis with Varimax rotation revealed six factors, as shown in Table 2. An eigenvalue greater than 1 was set as the criterion for selecting components, accounting for $78.651 \%$ of the total variance in the data set. The identified factors are referred to as profitability, short-term liquidity, financial structure, operating capability, long-term liquidity, and cash flow (see Table 2).

Then, we select a representative indicator in each factor. In this study, variables with factor loadings of greater than 0.83 were used to form the representative financial performance evaluation criteria. Thus, the 10 financial ratios in Table 2 were selected and used in the financial performance evaluation. The selected financial ratios include variables K6, K8, K9, K3, K2, K10, K5, K1, K4, and K7.

\subsection{Result of entropy weight values}

In this study, 10 financial ratio indicators were selected from the factor analysis procedure with RAROC as the evaluation criteria to evaluate the financial performance of Taiwan's listed opto-electronic companies. To compute the entropy weight, the first step is normalization of the data set. In line with Chen et al. (2000), and Chiang and Hsieh (2009), three different types of data normalization methods were used in this study. Among the 11 representative indicators, the K4 (accounts receivable in days) showed better properties when smaller. The other 10 variables were better when they were larger. After data normalization, by using the entropy weight method (Eq. (3)-(7)) the evaluation indicator weight of 2007 and 2008 can be obtained. The results are shown in Table 3.

The results in Table 3 show that the weight values in 2007 and 2008 had little difference. In 2007, K5 (fixed assets turnover) had the largest weight value of 0.0939 , while K6 (returns on equity) and K11 (RAROC) had the smallest values of 0.0898 . That is, the fixed assets turnover in the financial evaluation criteria had the greatest weight. The ROE and RAROC were given a small weight for evaluation criteria. The results for 2008 show that the cash flow adequacy ratio had the greatest weight $(\mathrm{K} 7=0.1124)$ and the RAROC had the smallest weight $(\mathrm{K} 11=0.0875)$.

Table 3. Entropy weights of the evaluation indicator

\begin{tabular}{cccccccccccc}
\hline Variable & K1 & K2 & K3 & K4 & K5 & K6 & K7 & K8 & K9 & K10 & K11 \\
\hline 2007 & 0.0922 & 0.0908 & 0.0910 & 0.0903 & 0.0939 & 0.0898 & 0.0899 & 0.0899 & 0.0899 & 0.0925 & 0.0898 \\
\hline 2008 & 0.0906 & 0.0889 & 0.0892 & 0.0877 & 0.0926 & 0.0876 & 0.1124 & 0.0876 & 0.0877 & 0.0882 & 0.0875 \\
\hline
\end{tabular}




\subsection{Results of the entropy-based TOPSIS model}

According to the results, 11 evaluation criteria were selected for financial performance evaluation of 50 listed opto-electronic companies in Taiwan. The entropy approach was used in determining the weights of the criteria and then the rankings of the companies were determined by the TOPSIS method.

In order to investigate the impact of the global financial turmoil on the financial performance of listed companies, this study employed the entropy-based TOPSIS model to evaluate the performances of the listed companies, and compared the results of 2007 and 2008. First, according to Eq. (11)-(12), we normalized the original data. In the performance measurement criteria for the selected variables, except for accounts receivable in days which were the smaller the better, the other 10 variables where the larger the better. Then, we substituted the results of the entropy weight (shown in Table 3) into Eq. (13) to obtain the weighted normalized decision matrix. By Eq. (14)-(17), the distance between the idea solution and negative ideal solution can be obtained $\left(S_{i}^{+}\right.$and $S_{i}^{-}$), as shown in Table 4. Finally, the closeness coefficient $\left(C_{i}\right)$ is conducted using Eq. (18), and used to rank the financial performance of the 50 listed companies (shown in Table 4).

The results of performance evaluation show that among the 50 listed companies in 2007 , the top three companies are companies 18,14 , and 20 , which have closeness coefficient values of $0.6135,0.5365$, and 0.4917 , respectively. That is, company 18 of the 50 listed companies had the best financial performance. For this company, the probability of financial distress is very low. Based on the results that company 50 had the smallest closeness coefficient of 0.1579 , that company's probability of financial distress is the highest.

Table 4. The results of entropy-based TOPSIS model for financial performance evaluation

\begin{tabular}{ccccccccccc}
\hline \multirow{2}{*}{ Company } & \multicolumn{4}{c}{2007} & & \multicolumn{2}{c}{2008} & \multicolumn{3}{c}{ Average } \\
\cline { 2 - 11 } & $S_{i}^{+}$ & $S_{i}^{-}$ & $C_{i}$ & Rank & $S_{i}^{+}$ & $S_{i}^{-}$ & $C_{i}$ & Rank & $C_{i}$ & Rank \\
\hline 1 & 0.1434 & 0.0570 & 0.2843 & 47 & 0.2019 & 0.0805 & 0.2851 & 48 & 0.2847 & 48 \\
\hline 2 & 0.1263 & 0.0782 & 0.3824 & 31 & 0.1806 & 0.1157 & 0.3905 & 25 & 0.3865 & 33 \\
\hline 3 & 0.1384 & 0.0681 & 0.3299 & 41 & 0.1951 & 0.0994 & 0.3376 & 45 & 0.3337 & 43 \\
\hline 4 & 0.1215 & 0.0781 & 0.3911 & 26 & 0.1782 & 0.1126 & 0.3872 & 29 & 0.3892 & 29 \\
\hline 5 & 0.1164 & 0.0933 & 0.4450 & 11 & 0.1782 & 0.1228 & 0.4080 & 14 & 0.4265 & 16 \\
\hline 6 & 0.1164 & 0.1045 & 0.4732 & 6 & 0.1815 & 0.1320 & 0.4211 & 9 & 0.4471 & 6 \\
\hline 7 & 0.1546 & 0.0399 & 0.2051 & 49 & 0.2093 & 0.0715 & 0.2548 & 49 & 0.2299 & 49 \\
\hline 8 & 0.1340 & 0.0709 & 0.3460 & 40 & 0.1905 & 0.0985 & 0.3407 & 43 & 0.3433 & 41 \\
\hline 9 & 0.1255 & 0.0856 & 0.4055 & 20 & 0.1875 & 0.1132 & 0.3763 & 34 & 0.3909 & 26 \\
\hline 10 & 0.1239 & 0.0949 & 0.4339 & 14 & 0.1843 & 0.1193 & 0.3930 & 23 & 0.4135 & 17 \\
\hline 11 & 0.1218 & 0.1029 & 0.4579 & 8 & 0.1824 & 0.1216 & 0.4000 & 17 & 0.4289 & 15 \\
\hline 12 & 0.1235 & 0.0894 & 0.4200 & 17 & 0.1784 & 0.1171 & 0.3962 & 22 & 0.4081 & 18 \\
\hline 13 & 0.1371 & 0.0747 & 0.3526 & 37 & 0.1718 & 0.1288 & 0.4284 & 6 & 0.3905 & 27 \\
\hline 14 & 0.1053 & 0.1219 & 0.5365 & 2 & 0.1907 & 0.1016 & 0.3475 & 40 & 0.4420 & 7 \\
\hline
\end{tabular}


Continued Table 4

\begin{tabular}{|c|c|c|c|c|c|c|c|c|c|c|}
\hline \multirow{2}{*}{ Company } & \multicolumn{4}{|c|}{2007} & \multicolumn{4}{|c|}{2008} & \multicolumn{2}{|c|}{ Average } \\
\hline & $S_{i}^{+}$ & $S_{i}^{-}$ & $C_{i}$ & Rank & $S_{i}^{+}$ & $S_{i}^{-}$ & $C_{i}$ & Rank & $C_{i}$ & Rank \\
\hline 15 & 0.1360 & 0.0771 & 0.3617 & 35 & 0.1677 & 0.1260 & 0.4289 & 5 & 0.3953 & 22 \\
\hline 16 & 0.1365 & 0.0729 & 0.3482 & 39 & 0.1939 & 0.1033 & 0.3476 & 39 & 0.3479 & 40 \\
\hline 17 & 0.1238 & 0.0903 & 0.4219 & 16 & 0.2035 & 0.0891 & 0.3046 & 47 & 0.3633 & 38 \\
\hline 18 & 0.0822 & 0.1304 & 0.6135 & 1 & 0.1736 & 0.1209 & 0.4105 & 13 & 0.5120 & 1 \\
\hline 19 & 0.1298 & 0.0850 & 0.3956 & 24 & 0.1499 & 0.1721 & 0.5345 & 1 & 0.4651 & 2 \\
\hline 20 & 0.1069 & 0.1034 & 0.4917 & 3 & 0.1854 & 0.1173 & 0.3874 & 28 & 0.4396 & 9 \\
\hline 21 & 0.1239 & 0.0749 & 0.3768 & 33 & 0.1550 & 0.1722 & 0.5263 & 2 & 0.4516 & 5 \\
\hline 22 & 0.1376 & 0.0760 & 0.3558 & 36 & 0.1734 & 0.1219 & 0.4127 & 12 & 0.3843 & 34 \\
\hline 23 & 0.1232 & 0.0874 & 0.4151 & 19 & 0.1859 & 0.1139 & 0.3799 & 33 & 0.3975 & 20 \\
\hline 24 & 0.1364 & 0.0733 & 0.3494 & 38 & 0.1780 & 0.1171 & 0.3967 & 21 & 0.3731 & 37 \\
\hline 25 & 0.1256 & 0.0793 & 0.3870 & 28 & 0.1798 & 0.1191 & 0.3984 & 19 & 0.3927 & 23 \\
\hline 26 & 0.1303 & 0.0885 & 0.4044 & 21 & 0.1897 & 0.1071 & 0.3608 & 37 & 0.3826 & 35 \\
\hline 27 & 0.1579 & 0.0525 & 0.2493 & 48 & 0.1911 & 0.1074 & 0.3598 & 38 & 0.3046 & 46 \\
\hline 28 & 0.1344 & 0.0888 & 0.3980 & 23 & 0.1871 & 0.1172 & 0.3851 & 31 & 0.3915 & 25 \\
\hline 29 & 0.1513 & 0.0616 & 0.2893 & 46 & 0.2104 & 0.0951 & 0.3113 & 46 & 0.3003 & 47 \\
\hline 30 & 0.1233 & 0.0726 & 0.3706 & 34 & 0.1744 & 0.1181 & 0.4037 & 16 & 0.3871 & 32 \\
\hline 31 & 0.1222 & 0.0978 & 0.4446 & 12 & 0.1699 & 0.1293 & 0.4321 & 4 & 0.4383 & 5 \\
\hline 32 & 0.1354 & 0.0845 & 0.3844 & 30 & 0.1884 & 0.1135 & 0.3760 & 35 & 0.3802 & 36 \\
\hline 33 & 0.1146 & 0.1087 & 0.4867 & 4 & 0.1825 & 0.1167 & 0.3900 & 26 & 0.4383 & 10 \\
\hline 34 & 0.1120 & 0.0894 & 0.4439 & 13 & 0.1657 & 0.1216 & 0.4233 & 8 & 0.4336 & 13 \\
\hline 35 & 0.1298 & 0.0936 & 0.4189 & 18 & 0.1894 & 0.1094 & 0.3662 & 36 & 0.3926 & 24 \\
\hline 36 & 0.1474 & 0.0649 & 0.3056 & 45 & 0.1798 & 0.1185 & 0.3973 & 20 & 0.3514 & 39 \\
\hline 37 & 0.1175 & 0.1014 & 0.4632 & 7 & 0.1743 & 0.1247 & 0.4171 & 10 & 0.4401 & 8 \\
\hline 38 & 0.1300 & 0.0792 & 0.3785 & 32 & 0.1817 & 0.1208 & 0.3993 & 18 & 0.3889 & 31 \\
\hline 39 & 0.1154 & 0.1082 & 0.4840 & 5 & 0.1759 & 0.1318 & 0.4284 & 7 & 0.4562 & 3 \\
\hline 40 & 0.1446 & 0.0681 & 0.3202 & 43 & 0.1961 & 0.1001 & 0.3379 & 44 & 0.3290 & 44 \\
\hline 41 & 0.1309 & 0.0842 & 0.3913 & 25 & 0.1823 & 0.1151 & 0.3869 & 30 & 0.3891 & 30 \\
\hline 42 & 0.1405 & 0.0629 & 0.3092 & 44 & 0.1912 & 0.0992 & 0.3416 & 42 & 0.3254 & 45 \\
\hline 43 & 0.1169 & 0.0971 & 0.4538 & 9 & 0.1727 & 0.1231 & 0.4161 & 11 & 0.4350 & 12 \\
\hline 44 & 0.1334 & 0.0853 & 0.3900 & 27 & 0.1848 & 0.1182 & 0.3900 & 27 & 0.3900 & 28 \\
\hline 45 & 0.1250 & 0.0832 & 0.3996 & 22 & 0.1820 & 0.1170 & 0.3912 & 24 & 0.3954 & 21 \\
\hline 46 & 0.1252 & 0.0924 & 0.4247 & 15 & 0.1883 & 0.1157 & 0.3806 & 32 & 0.4027 & 19 \\
\hline 47 & 0.1252 & 0.1039 & 0.4536 & 10 & 0.1834 & 0.1256 & 0.4065 & 15 & 0.4300 & 14 \\
\hline 48 & 0.1292 & 0.0814 & 0.3867 & 29 & 0.1484 & 0.1599 & 0.5186 & 3 & 0.4526 & 4 \\
\hline 49 & 0.1373 & 0.0663 & 0.3255 & 42 & 0.1935 & 0.1017 & 0.3444 & 41 & 0.3350 & 42 \\
\hline 50 & 0.1584 & 0.0297 & 0.1579 & 50 & 0.2177 & 0.0654 & 0.2311 & 50 & 0.1945 & 50 \\
\hline
\end{tabular}

Notes: $S_{i}^{+}$: ideal solution; $S_{i}^{-}$: negative ideal solution; $C_{i}$ : closeness coefficient. 
The results in Table 4 indicate that in the performance evaluation in 2008 the top three rankings were company 19 (0.5345), 21 (0.5263), and 48 (0.5186), respectively. Among the 50 listed companies, company 50 had the worst financial performance in $2008(0.2311)$.

We calculated the average closeness coefficient values of 2007 and 2008, and based on the results of sorting, the average ranking performance can be obtained, as shown in Table 4. According to the average performance rankings in the two years, company 18 ranked first, company 19 was second and company 39 ranked third. In the financial performance ranking order, the last three companies were companies 1,7 , and 50.

\subsection{Results of Spearman and Kendall rank coefficients}

In order to understand the rank correlation between 2007 and 2008, Spearman rank correlations and Kendall's coefficient of concordance were used in this study. The results of rank correlation tests show that the values of both Spearman $\left(\gamma_{S}\right)$ and Kendall $(\tau)$ are positive and significant $\mathrm{P}<0.05\left(\gamma_{S}=0.44\right.$, P-value $=0.000 ; \tau=0.306$, P-value $=0.000$ ). Because $\mathrm{P}<0.05$, therefore reject the null hypothesis that assumes there is no significant relationship between the ranking results between 2007 and 2008. Further, the results indicate that the correlation coefficients were generally low (less than 0.5). Thus, there was a weak positive correlation of ranking results.

\section{Conclusion and recommendation}

The main purpose of this paper was to include risk variables (RAROC) in evaluation criteria, and to construct a financial performance evaluation process. First, we used factor analysis to find representative indicators from financial ratios and combined them with the RAROC as the evaluation of financial performance criteria. Second, we used the entropy weight method to determine the weight of each evaluation indicators. Finally, we applied TOPSIS to evaluate the financial performance of Taiwan's 50 listed opto-electronic companies.

By conducting factor analysis among the 20 financial ratios and the 10 selected representative indicators with RAROC variables, a total of 11 variables were used in this study to construct a financial performance evaluation model. Entropy weighting results show the maximum entropy value among financial ratios in 2007 and 2008 were the fixed assets turnover and cash flow adequacy ratios, respectively. In regard to financial performance rankings, the results of the TOPSIS method showed that there was some change in the order of Taiwan's 50 listed opto-electronic companies in 2007 and 2008. The results of both Spearman's and Kendall's rank correlation analysis reveal that a positive, weak correlation was found between the financial performance ranks of 2007 and 2008. This shows that the global financial turmoil in 2008 affected the financial performance of the companies, leading to changes in the rankings.

Because of the global financial turmoil, the companies' stock prices were highly volatile. This led to the deterioration of the financial situation and the risk of holding stocks for investors also increased. Therefore, this study suggests that when constructing a financial performance evaluation model, the capital risk of the measured variable RAROC should be considered in order to truly reflect the results of the evaluation. 


\section{References}

Abo-Sinna, M. A.; Amer, A. H. 2005. Extensions of TOPSIS for multi-objective large-scale nonlinear programming problems, Applied Mathematics and Computation 162(1): 243-256. http://dx.doi.org/10.1016/j.amc.2003.12.087

Alinezhad, A.; Makui, A.; Kiani Mavi, R.; Zohrehbandian, M. 2011. An MCDM-DEA approach for technology selection, Journal of Industrial Engineering International 7(12): 32-38.

Antucheviciene, J; Zavadskas, E. K. 2008. Modelling multidimensional redevelopment of derelict buildings, International Journal of Environment and Pollution 35(2-3-4): 331-344.

http://dx.doi.org/10.1504/IJEP.2008.021364

Athawale, V. M.; Chakraborty, S. 2011. A comparative study on the ranking performance of some multi-criteria decision-making methods for industrial robot selection, International Journal of Industrial Engineering Computations 2(4): 831-850. http://dx.doi.org/10.5267/j.ijiec.2011.05.002

Baležentis, A.; Baležentis, T.; Valkauskas, R. 2010. Evaluating situation of Lithuania in the European Union: structural indicators and MULTIMOORA method, Technological and Economic Development of Economy 16(4): 578-602. http://dx.doi.org/10.3846/tede.2010.36

Behzadian, M.; Kazemzadeh, R. B.; Albadvi, A.; Aghdasi, M. 2010. PROMETHEE: a comprehensive literature review on methodologies and applications, European Journal of Operational Research 200(1): 198-215. http://dx.doi.org/10.1016/j.ejor.2009.01.021

Brauers, W. K. M.; Ginevičius, R. 2010. The economy of the Belgian regions tested with MULTIMOORA, Journal of Business Economics and Management 11(2): 173-209.

http://dx.doi.org/10.3846/jbem.2010.09

Brauers, W. K. M.; Ginevičius, R.; Podvezko, V. 2010. Regional development in Lithuania considering multiple objectives by the MOORA method, Technological and Economic Development of Economy 16(4): 613-640. http://dx.doi.org/10.3846/tede.2010.38

Brauers, W. K. M.; Zavadskas, E. K. 2010. Project management by MULTIMOORA as an instrument for transition economies, Technological and Economic Development of Economy 16(1): 5-24. http://dx.doi.org/10.3846/tede.2010.01

Brauers, W. K. M.; Baležentis, A.; Baležentis, T. 2011. MULTIMOORA for the EU Member States updated with fuzzy number theory, Technological and Economic Development of Economy 17(2): 259-290. http://dx.doi.org/10.3846/20294913.2011.580566

Chakraborty, S. 2011. Applications of the MOORA method for decision making in manufacturing environment, International Journal of Advanced Manufacturing 54(9-12): 1155-1166. http://dx.doi.org/10.1007/s00170-010-2972-0

Chang, C. H.; Lin, J. J.; Lin, J. H.; Chiang, M. C. 2010. Domestic open-end equity mutual fund performance evaluation using extended TOPSIS method with different distance approaches, Expert Systems with Applications 37(6): 4642-4649. http://dx.doi.org/10.1016/j.eswa.2009.12.044

Charbaji, A. 2001. Developing a model to restructure the overpopulated banking industry in Lebanon, Managerial Auditing Journal 16(1): 28-35. http://dx.doi.org/10.1108/02686900110363456

Charitou, A.; Neophytou, E.; Charalambous, C. 2004. Predicting corporate failure: empirical evidence for the UK, European Accounting Review 13(3): 465-497.

http://dx.doi.org/10.1080/0963818042000216811

Chen, C. B.; Lin, C. T.; Chang, C. W.; Ho, C. 2000. Grey relation for solving multi-quality characteristics problems of Taguchi methods, Journal of Technology 15(1): 25-33.

Cheng, F.; Arif, M. 2007. Abnormal returns of bank stocks and their factor-analysed determinants, Journal of Accounting, Business and Management 14: 1-7.

Chiang, Y. M.; Hsieh, H. H. 2009. The use of the Taguchi method with grey relational analysis to optimize the thin-film sputtering process with multiple quality characteristic in color filter 
manufacturing, Computers \& Industrial Engineering 56(2): 648-661.

http://dx.doi.org/10.1016/j.cie.2007.12.020

Chou, J. R.; Tsai, H. C. 2009. On-line learning performance and computer anxiety measure for unemployed adult novices using a grey relation entropy method, Information Processing \& Management 45(2): 200-215. http://dx.doi.org/10.1016/j.ipm.2008.12.001

Deng, H.; Yeh, C. H.; Willis, R. J. 2000. Inter-company comparison using modified TOPSIS with objective weights, Computers \& Operations Research 27(10): 963-973.

http://dx.doi.org/10.1016/S0305-0548(99)00069-6

Ertuğrul, İ.; Karakaşoğlu, N. 2009. Performance evaluation of Turkish cement firms with fuzzy analytic hierarchy process and TOPSIS methods, Expert Systems with Applications 36(1): 702715. http://dx.doi.org/10.1016/j.eswa.2007.10.014

Farzam, A. F. 2009. Risk-Adjusted Return on Capital as a Concept in Value-Based Logistics Management. Wydawnictwo: GRIN Verlag.

Froot, K. A.; Stein, J. C. 1998. A new approach to capital budgeting for financial institutions, Journal of Applied Corporate Finance 11(2): 59-69.

http://dx.doi.org/10.1111/j.1745-6622.1998.tb00648.x

Gadakh, V. S. 2011. Application of MOORA method for parametric optimization of milling process, International Journal of Applied Engineering Research 1(4): 743-758.

Ginevičius, R.; Podvezko, V.; Raslanas, S. 2008. Evaluating the alternative solutions of wall insulation by multicriteria methods, Journal of Civil Engineering and Management 14(4): 217-226. http://dx.doi.org/10.3846/1392-3730.2008.14.20

Ginevičius, R.; Krivka, A.; Šimkūnaite, J. 2010. The model of forming competitive strategy of an enterprise under the conditions of oligopolic market, Journal of Business Economics and Management 11(3): 367-395. http://dx.doi.org/10.3846/jbem.2010.18

Han, Z. S.; Liu, P. D. 2011. A fuzzy multi-attribute decision-making method under risk with unknown attribute weights, Technological and Economic Development of Economy 17(2): 246-258. http://dx.doi.org/10.3846/20294913.2011.580575

Hsu, P. F.; Hsu, M. G. 2008. Optimizing the information outsourcing practices of primary care medical organizations using entropy and TOPSIS, Quality and Quantity 42(2): 181-201.

http://dx.doi.org/10.1007/s11135-006-9040-8

Hwang, C. L.; Yoon, K. 1981. Multiple Attribute Decision Making: Methods and Applications. New York: Springer-Verlag. http://dx.doi.org/10.1007/978-3-642-48318-9

Kaklauskas, A.; Zavadskas, E. K.; Naimaviciene, J.; Krutinis, M.; Plakys, V.; Venskus, D. 2010. Model for a complex analysis of intelligent built environment, Automation in Construction 19(3): 326-340. http://dx.doi.org/10.1016/j.autcon.2009.12.006

Karandikar, R.; Khaparde, S.; Kulkarni, S. 2007. Quantifying price risk of electricity retailer based on CAPM and RAROC methodology, International Journal of Electrical Power and Energy Systems 29(10): 803-809. http://dx.doi.org/10.1016/j.ijepes.2007.06.007

Kendall, M. G. 1970. Rank Correlation Methods. $4^{\text {th }}$ ed. London: Griffin.

Keršulienè, V.; Zavadskas, E. K.; Turskis, Z. 2010. Selection of rational dispute resolution method by applying new step-wise weight assessment ratio analysis (SWARA), Journal of Business Economics and Management 11(2): 243-258. http://dx.doi.org/10.3846/jbem.2010.12

Kildiene, S.; Kaklauskas, A.; Zavadskas, E. K. 2011. COPRAS based comparative analysis of the European country management capabilities within the construction sector in the time of crisis, Journal of Business Economics and Management 12(2): 417-434.

http://dx.doi.org/10.3846/16111699.2011.575190

Laitinen, E. K. 2000. Long-term success of adaptation strategies: evidence from Finnish companies, Long Range Planning 33(6): 805-830. http://dx.doi.org/10.1016/S0024-6301(00)00088-1 
Liu, L.; Zhou, J.; An, X.; Zhang, Y.; Yang, L. 2010. Using fuzzy theory and information entropy for water quality assessment in Three Gorges Region, China, Expert Systems with Applications 37(3): 2517-2521. http://dx.doi.org/10.1016/j.eswa.2009.08.004

Liu, P. D. 2009. Multi-attribute decision-making method research based on interval vague set and TOPSIS method, Technological and Economic Development of Economy 15(3): 453-463. http://dx.doi.org/10.3846/1392-8619.2009.15.453-463

Liu, P. D. 2011a. The study on venture investment evaluation based on linguistic variables for Chinese case, Journal of Business Economics and Management 12(2): 219-233.

http://dx.doi.org/10.3846/16111699.2011.573284

Liu, P. D. 2011b. An extended TOPSIS method for multiple attribute group decision making based on generalized interval-valued trapezoidal fuzzy numbers, Informatica 35(2): 185-196.

Liu, P. D. 2011c. A novel method for multiple attribute decision-making of continuous random variable under risk with attribute weight unknown, Mathematical and Computational Applications 16(2): 340-349.

Machfoedz, M. 1994. Financial ratio analysis and the prediction of earnings changes in Indonesia, Kelola 7(3): 114-134.

Medineckiene, M.; Turskis, Z.; Zavadskas, E. K. 2010. Sustainable construction taking into account the building impact on the environment, Journal of Environmental Engineering and Landscape Management 18(2): 118-127. http://dx.doi.org/10.3846/jeelm.2010.14

Öcal, M. E.; Oral, E. L.; Erdis, E.; Vural, G. 2007. Industry financial ratios-application of factor analysis in Turkish construction industry, Building and Environment 42(1): 385-392.

http://dx.doi.org/10.1016/j.buildenv.2005.07.023

Ou Yang, Y. P.; Shieh, H. M.; Tzeng, G. H. 2011. A VIKOR Technique based on DEMATEL and ANP for information security risk control assessment, Information Sciences [Forthcoming]. http://dx.doi.org/10.1016/j.ins.2011.09.012

Parthiban, P.; Punniyamoorthy, M.; Ganesh, K.; Janardhana, G. R. 2010. Development and assessment of modified VIKOR method for multi-criteria single sourcing in supply chain, International Journal of Business and Systems Research 4(1): 94-116.

http://dx.doi.org/10.1504/IJBSR.2010.029950

Podvezko, V.; Mitkus, S.; Trinkūnienè, E. 2010. Complex evaluation of contracts for construction, Journal of Civil Engineering and Management 16(2): 287-297.

http://dx.doi.org/10.3846/jcem.2010.33

Podvezko, V.; Podviezko, A. 2010. Dependence of multi-criteria evaluation result on choice of preference functions and their parameters, Technological and Economic Development of Economy 16(1): 143-158. http://dx.doi.org/10.3846/tede.2010.09

Podvezko, V. 2011. The comparative analysis of MCDA methods SAW and COPRAS, Inzinerine Ekonomika - Engineering Economics 22(2): 134-146. http://dx.doi.org/10.5755/j01.ee.22.2.310

Radziszewska-Zielina, E. 2010. Methods for selecting the best partner construction enterprise in terms of partnering relations, Journal of Civil Engineering and Management 16(4): 510-520. http://dx.doi.org/10.3846/jcem.2010.57

Rathore, A. S.; Prasad, H.; Jodhana, L. S. 2010. Financial performance of Rajasthan tourism development corporation (RTDC): an analysis, South Asian Journal of Tourism and Heritage 3(1): 129-135.

Saparauskas, J.; Zavadskas, E. K.; Turskis, Z. 2011. Selection of facade's alternatives of commercial and public buildings based on multiple criteria, International Journal of Strategic Property Management 15(2): 189-203. http://dx.doi.org/10.3846/1648715X.2011.586532

Seçme, N. Y. I.; Bayrakdaroglu, A.; Kahraman, C. 2009. Fuzzy performance evaluation in Turkish banking sector using analytic hierarchy process and TOPSIS, Expert Systems with Applications 36(9): 11699-11709. http://dx.doi.org/10.1016/j.eswa.2009.03.013 
Shan, L. 2011. Research on logistics service providers selection based on AHP and VIKOR, Intelligent Computing and Information Science 134: 93-98.

http://dx.doi.org/10.1007/978-3-642-18129-0_15

Shanian, A.; Savadogo, O. 2009. A methodological concept for material selection of highly sensitive components based on multiple criteria decision analysis, Expert Systems with Applications 36(2): 1362-1370. http://dx.doi.org/10.1016/j.eswa.2007.11.052

Shannon, C. E. 1948. A mathematical theory of communication, Bell System Technical Journal 27(3): 379-423.

Shannon, C. E.; Weaver, W. 1949. The Mathematical Theory of Communication. Urbana: The University of Illinois.

Shih, H. S.; Shyur, H. J.; Lee, E. S. 2007. An extension of TOPSIS for group decision making, Mathematical and Computer Modelling 45(7-8): 801-813.

http://dx.doi.org/10.1016/j.mcm.2006.03.023

Sivilevičius, H.; Maskeliūnaitè, L. 2010. The criteria for identifying the quality of passengers' transportation by railway and their ranking using AHP method, Transport 25(4): 368-381.

http://dx.doi.org/10.3846/transport.2010.46

Spearman, C. 1904. The proof and measurement of association between two things, The American Journal of Psychology 15(1): 72-101. http://dx.doi.org/10.2307/1412159

Tomić-Plazibat, N.; Aljinović, Z.; Pivac, S. 2010. Risk assessment of transitional economies by multivariate and multicriteria approaches, Panoeconomicus 57(3): 283-302.

http://dx.doi.org/10.2298/PAN1003283T

Tupenaite, L.; Zavadskas, E. K.; Kaklauskas, A.; Turskis, Z.; Seniut, M. 2010. Multiple criteria assessment of alternatives for built and human environment renovation, Journal of Civil Engineering and Management 16(2): 257-266. http://dx.doi.org/10.3846/jcem.2010.30

Turskis, Z.; Zavadskas, E. K. 2010. A new fuzzy additive ratio assessment method (ARAS-F). Case study: the analysis of fuzzy multiple criteria in order to select the logistic centers location, Transport 25(4): 423-432. http://dx.doi.org/10.3846/transport.2010.52

Ulubeyli, S.; Kazaz, A. 2009. A multiple criteria decision-making approach to the selection of concrete pumps, Journal of Civil Engineering and Management 15(4): 369-376.

http://dx.doi.org/10.3846/1392-3730.2009.15.369-376

Uzsilaityte, L.; Martinaitis, V. 2010. Search for optimal solution of public building renovation in terms of life cycle, Journal of Environmental Engineering and Landscape Management 18(2): 102-110. http://dx.doi.org/10.3846/jeelm.2010.12

Walsh, C. 1996. Key Management Ratios: How to Analyse, Compare, and Control the Figures That Drive Company Value. London: Financial Times/Prentice Hall.

Wang, J. J.; Jing, Y. Y.; Zhang, C. F.; Zhang, X. T.; Shi, G. H. 2008. Integrated evaluation of distributed triple-generation systems using improved grey incidence approach, Energy 33(9): 1427-1437. http://dx.doi.org/10.1016/j.energy.2008.04.008

Wang, T. C.; Lee, H. D. 2009. Developing a fuzzy TOPSIS approach based on subjective weights and objective weights, Expert Systems with Applications 36(5): 8980-8985.

http://dx.doi.org/10.1016/j.eswa.2008.11.035

Wang, X.; Triantaphyllou, E. 2008. Ranking irregularities when evaluating alternatives by using some ELECTRE methods, Omega 36(1): 45-63. http://dx.doi.org/10.1016/j.omega.2005.12.003

Wang, Y. J. 2008. Applying FMCDM to evaluate financial performance of domestic airlines in Taiwan, Expert Systems with Applications 34(3): 1837-1845.

http://dx.doi.org/10.1016/j.eswa.2007.02.029 
Wang, Y. J. 2009. Combining grey relation analysis with FMCGDM to evaluate financial performance of Taiwan container lines, Expert Systems with Applications 36(2): 2424-2432. http://dx.doi.org/10.1016/j.eswa.2007.12.027

Wilcke, M. T.; Abbaszadegan, H.; Adolphson, P. Y. 2009. Evaluation of a Swedish version of the patient-rated wrist evaluation outcome questionnaire: good responsiveness, validity, and reliability, in 99 patients recovering from a fracture of the distal radius, Scandinavian Journal of Plastic and Reconstructive Surgery and Hand Surgery 43(2): 94-101.

http://dx.doi.org/10.1080/02844310902734598

Wu, C. R.; Chang, C. W.; Lin, H. L. 2007. An organisational performance measurement model based on AHP sensitivity analysis, International Journal of Business Performance Management 9(1): 77-91. http://dx.doi.org/10.1504/IJBPM.2007.011497

Xie, G.; Zhang, J.; Lai, K.; Yu, L. 2008. Variable precision rough set for group decision-making: an application, International Journal of Approximate Reasoning 49(2): 331-343.

http://dx.doi.org/10.1016/j.ijar.2007.04.005

Yu, V. F.; Hu, K. J. 2010. An integrated fuzzy multi-criteria approach for the performance evaluation of multiple manufacturing plants, Computers \& Industrial Engineering 58(2): 269-277. http://dx.doi.org/10.1016/j.cie.2009.10.005

Yurdakul, M.; İç, Y. T. 2004. AHP approach in the credit evaluation of the manufacturing firms in Turkey, International Journal of Production Economics 88(3): 269-289.

http://dx.doi.org/10.1016/S0925-5273(03)00189-0

Zavadskas, E. K.; Turskis, Z.; Vilutiene, T. 2010a. Multiple criteria analysis of foundation instalment alternatives by applying Additive Ratio Assessment (ARAS) method, Archives of Civil and Mechanical Engineering 10(3): 123-141. http://dx.doi.org/10.1016/S1644-9665(12)60141-1

Zavadskas, E. K.; Vilutiene, T.; Turskis, Z.; Tamosaitiene, J. 2010b. Contractor selection for construction works by applying SAW-G and TOPSIS Grey techniques, Journal of Business Economics and Management 11(1): 34-55. http://dx.doi.org/10.3846/jbem.2010.03

Zavadskas, E. K.; Turskis, Z. 2011. Multiple criteria decision making (MCDM) methods in economics: an overview, Technological and Economic Development of Economy 17(2): 397-427. http://dx.doi.org/10.3846/20294913.2011.593291

Zopounidis, C.; Dimitras, A. I. 1998. Multicriteria Decision Aid Methods for the Prediction of Business Failure. Dordrecht: Kluwer Academic Publishers.

Zou, Z.; Yun, Y.; Sun, J. 2006. Entropy method for determination of weight of evaluating indicators in fuzzy synthetic evaluation for water quality assessment, Journal of Environmental Sciences 18(5): 1020-1023. http://dx.doi.org/10.1016/S1001-0742(06)60032-6

Žvirblis, A.; Buračas, A. 2010. The consolidated measurement of the financial markets development: the case of transitional economies, Technological and Economic Development of Economy 16(2): 266-279. http://dx.doi.org/10.3846/tede.2010.17

Li-Chang HSU is an associate professor of economics at Ling Tung University, Taiwan. His research areas are decision making theory, grey system theory, technology management and strategy management. His articles are published by British Journal of Management, Service Business, Journal of Electronic Commerce Research, Technological Forecasting and Social Change, Expert Systems with Application, and others. 